\title{
An investigation of career change using a narrative and story-telling inquiry
}

\author{
Author: \\ Willie T. Chinyamurindi ${ }^{1}$ \\ Affiliation: \\ ${ }^{1}$ Department of \\ Management, Open \\ University Business School, \\ United Kingdom \\ Correspondence to: \\ Willie Chinyamurindi \\ Email: \\ chinyaz@gmail.com \\ Postal address: \\ The Open University Business \\ School, Walton Hall, Milton \\ Keynes MK7 6AA, United \\ Kingdom \\ Dates: \\ Received: 17 Nov. 2011 \\ Accepted: 17 Oct. 2012 \\ Published: 05 Dec. 2012 \\ How to cite this article: \\ Chinyamurindi, W.T. (2012). \\ An investigation of career \\ change using a narrative \\ and story-telling inquiry. SA \\ Journal of Human Resource \\ Management/SA Tydskrif vir \\ Menslikehulpbronbestuur, \\ 10(2), Art. \#447, 11 pages. \\ http://dx.doi.org/10.4102/ \\ sajhrm.v10i2.447
}

C 2012. The Authors. Licensee: AOSIS OpenJournals. This work is licensed under the Creative Commons Attribution License.
Orientation: The role of the career change experience has been investigated in this research. Understanding career change will assist with organisational interventions for the support and retention of employees.

Research purpose: The study explores the factors that influence career change amongst a sample of distance learners.

Motivation for the study: Distance learning is becoming popular in South Africa as individuals can work and learn simultaneously. Some people use distance learning to facilitate career change.

Research design, approach and method: A narrative and storytelling inquiry was used. Data was obtained through unstructured interviews by purposive sampling.

Main findings: Sources of career change included personal growth and ambition, and structural changes in relation to current work. The career change experience was found through participants' stories and narratives to influence individual well-being. Finally, distance learning was favoured as a vehicle for career change for its flexibility and low cost.

Practical/managerial implications: Organisations will benefit from an understanding of employee career change experiences as identified in this study. Arising from this, support and retention interventions can be put in place.

Contribution/value-add: The research study shifts attention to career change as part of the career decision-making process. This focus is an emerging area of inquiry in the careers literature. This adds to the body of knowledge by identifying, in a South African context, the factors influencing career change and the impact of this on the individual. Interventions for individuals and organisations are suggested.

\section{Introduction}

In recent years, the practice of an individual holding one job or remaining with one organisation is being replaced with periodic employment, change of professions and organisations (Hall, 2004). Several reasons have been suggested to explain this change in employment patterns.

Changes happening in the global competitive business environment, coupled with the increasing demand for employability in the knowledge economy, have resulted in changes in the workplace and career development (Arnold \& Cohen, 2008; Baruch, 2004; Herr, Cramer \& Niles, 2004). Chudzikowski (2012) suggested that careers in the present day are characterised by the need to remain employable, flexible and maintain market value. This quest may result in individuals pursuing diverse career paths and shifts in organisational loyalties (Baruch, 2004; Marshall \& Bonner, 2003; Suutari \& Taka, 2004).

In addition to this, individuals in such economies appear to have multiple identities (Ibarra, 2003) and commitments (Cohen, 2003). All these serve as possible reasons for periodic employment characterised by change of professions and organisations by the individual.

This study investigated the phenomenon of career change amongst a sample of previously disadvantaged distance learners in South Africa. Previously disadvantaged individuals in South African consist of Black Africans, Indians, Chinese South Africans, mixed-race people, women, youth, the disabled and people residing in rural communities (Cottrell, 2005). These people play an important contribution to the South African economy although having being marginalised by the laws of apartheid.

Apartheid entailed a policy of 'separateness' (Cottrell, 2005, pp. 14-15) and meant that educational, job and career opportunities were classified by race (Stead \& Watson, 2006). This 
resulted in limited employment and career opportunities for the Black populace.

Efforts through acts of law have been introduced targeted at benefiting individuals disadvantaged by apartheid. These laws strive to achieve parity and equity in South Africa given the historical legacy of apartheid (Czakan, 2006). At the core of this, empowering individuals previously disadvantaged by apartheid is recognised as key (Booysen, 2000).

One way to achieve this was through a number of interventions targeted at the role of education and skills development (Toni \& Olivier, 2004). One such intervention aimed at removing barriers of access that impede previously disadvantaged individuals from attaining an education (South African Department of Education, 1997). With this intervention, the role of distance learning, especially amongst previously disadvantaged individuals, was affirmed as important (South African Department of Education, 2010). Its popularity stems from a range of reasons.

Firstly, distance learning meets the needs of rural communities - learning taking place, albeit at a physical distance (South African Department of Education, 1997). Secondly, distance learning suits the socioeconomic situations of the previously disadvantaged (Glennie \& Bialobrzeska, 2006). Thirdly, distance learning allows for flexibility between work and study (Lemmer, 2009). Fourthly, distance learning is a cheaper mode of study to full-time enrolment (Msila, 2006; South African Department of Education, 1997, 2010).

In essence, distance learning in South Africa is viewed as a tool for upward mobility (Lemmer, 2009) through the attainment of skills. This role of distance learning has been suggested to have an impact also on individual career development (Burgess \& Russell, 2003). Research in South Africa has predominantly investigated the role of education on career development outside the distance-learning context (Geldenhuys \& De Lange, 2007; Jordaan, Smithard \& Burger, 2009; Myburgh, 2005; Watson, Brand, Stead \& Ellis, 2001). This gap in the research led to this study.

Although the career planning process is often described in developmental terms as composed of careful planning and reasoning (McMahon, 2006), there is growing emphasis that the process is actually characterised by tangential movements and disjointed choices, and is based on the emergence of opportunities (Bloch, 2005). This is worth investigating especially in contexts such as South Africa where opportunities appear to be emerging for previously disadvantaged individuals.

An overlooked aspect of career development is that of the career change experience which includes 'frustration' and the 'potential impact on career decisions' (Young, 2009, p. 282). This presented an opportunity for this research study to investigate career change amongst a sample of previously disadvantaged distance learners in South Africa.

\section{Research objectives}

The main research aim was to understand the career change experience amongst a sample of previously disadvantaged distance learners. This includes the factors influencing individual career change experience. The research study is located in the distance-learning context which is identified as being important especially concerning issues of affirmative action and social justice.

In addition to this, such a context does not only have potential with regard to issues of access to education but also individual career development. Thus, this study investigated the career change experience in a distance-learning context. The research question was set as follows: 'What factors affect the career change experience and what role does distance learning play in this experience amongst a sample of distance learners in South Africa?'

Arising from this, interventions on an individual and organisational level that influence support and retention strategies can be proposed. The next section presents a review of the literature on career development and career change. The methodology and analysis procedure used in the study follow. Thereafter, the results are presented together with a subsequent discussion. Finally, the conclusion and recommendations receive attention.

\section{Career decision-making and career change}

Various definitions of a career have been proposed in the extant literature. Hall (2002) viewed a career as consisting of an individual's sequence of perceived work roles. This has been suggested to include the roles of students or those in formal and informal work (Baruch, 2004). The aim in the process of career development is one of individual 'selfdevelopment' (Maree, 2002, p. 9) and empowerment of the individual (Savickas et al., 2009).

The process of career change in this study was defined as 'movement across occupational boundaries' (Hess, Jepsen \& Dries, 2012, p. 280). This also represents a possible move from paid to unpaid work done by an individual or the change from wage employment in an organisation to selfemployment from home or vice-versa (Rhodes, 2000).

Through a range of theoretical frameworks and empirical studies, the literature identifies a number of factors that influence the individual career decision-making process and that can subsequently inform career change.

\section{Theoretical development}

Using Bem's (1967) self-perception theory, focus is on how an individual defines him or herself based on behaviours and perception of the self. In some cases, the source of decisionmaking (including career change) is based on a desired image and managing its perception to others (Bono \& Vey, 2007; Chen \& Fang, 2008). Thus, this perception can act as a 
driver of decisions and behaviour (McFarland, Yun, Harold, Viera \& Moore, 2005).

An alternate view of understanding career decision-making is through the lens of trait and factor theories (Holland, 1992, 1997). This occurs in three steps (Stead \& Watson, 2006, p. 15). Firstly, an individual needs to have a clear understanding of him or herself, including their ability, attitude, interest, ambition and limitations. A 'trait' is thus defined as referring to the characteristics of the individual who is making a career decision. Secondly, the 'factors' should include requirements from the different occupations of the individuals. Thirdly, a match between traits and factors should be achieved.

It is assumed that the better the relation between the traits and the factors, the more accurate the match will be. In essence, career change as a decision can occur influenced by these individual traits or factors. Some empirical studies can be cited as being grounded in trait and factor theories. Oleski and Subich (1996) utilised Holland's code for current and intended occupation on a sample of workers. The study found that a relationship existed between participants' intended occupation in relation to life satisfaction when compared to their current occupation. In essence, the workers' view of their future in an occupation was related to their life satisfaction based on a consideration of individual traits and factors.

Concerns have been raised with using traits and factors as predictors of decision-making. Herr and Cramer (1992) questioned whether traits and factors alone can be accurate predictors of individual career decision-making. An omission to this theory is the role of other factors, such as individual background, including the nuances of socioeconomic factors on decision- making. This omission is viewed as making trait and factor theories oversimplified with regard to career decision-making (Savickas et al., 2009).

Career decision-making can also be understood through the lens of social learning theory. The literature identifies that through reinforcement and feedback (Mitchell \& Krumboltz, 1996) this may lead to the making of career decisions (Krumboltz, 1979). This also creates a basis by which individuals prepare and understand the world of work (Gibson \& Mitchell, 1999).

A number of ways have been found in which individuals can make career decisions hinging on social learning theory. These are:

- formal and informal learning (Brown, Bimrose, Barnes \& Hughes, 2012)

- academic pursuits and the feedback from this (Lent, Brown \& Hackett, 2002)

- the influence of the media and role models through a process of learning by association (Inkson, 2007).

These all attest to tenets held in the social learning theory of career decision-making (Krumboltz, 1979; Mitchell \& Krumboltz, 1996). In essence, these may also inform decisions around career change. The developmental view of career decision-making also receives attention.

The developmental view of decision-making assumes that the process occurs through individual careful planning and reasoning (McMahon, 2006). These tenets have been argued by various theories. For example, the work of Donald Super (Super, 1990) has been seminal. The main themes of Super's work assumed that career development was influenced by age. In this respect, individuals develop in a predictable stageby-stage manner in response to their choices or commitment towards work or a goal. Super believed that individuals achieve this well when they have a crystallised self-concept (Super, 1984). This crystallised self-concept was thought to be an enabler (through abilities, interests, personality traits and values) in making career choices.

Super further argued that the ability to make career choices changes with time (Super, Tiedeman \& Borrow, 1961) eventually leading to vocational maturity (Super, 1990). He also believed time (past, present and future) to be central to individual career development. This time factor was further embedded in Super's Life-Career Rainbow (Super, 1990). Emphasis was placed on the interaction between individual roles and stages of development in informing career development.

The findings from empirical work hinging on Super's developmental theory appear tenuous and raise more questions than they do answers. In South Africa, much of the theorising has hinged on the developmental view of careers. This has mostly been investigated using the survey approach relying on instruments mostly from North America (Bosch, De Bruin, Kgaladi \& De Bruin, 2012; Creed, Patton \& Watson, 2002; Du Toit \& De Bruin, 2002; Jordaan et al., 2009; Myburgh, 2005; Patton, Creed \& Watson, 2003; Schultheiss \& Stead, 2004; Stead \& Chetty, 2002; Watson et al., 2001). Using such techniques has helped to identify factors that influence career decision-making including the career development process. However, some concerns can be raised.

Firstly, this research study argues for the need to go beyond simply identifying factors and endeavours to understand how these factors holistically influence career development as a process. This is where a qualitative understanding of careers can be worthwhile, especially when investigating a 'personal' and 'highly complex' subject matter such as career change (Wise \& Milward, 2005, p. 401).

Secondly, aspects of contextual differences bring into question the relevance of such methods and their reliance on Western instruments in South Africa (Stead, 2007). It has been noted that differences between countries do exist (Creed et al., 2002; Patton et al., 2003). This brings to light issues regarding the cross-cultural applicability of these Western instruments and their relevance in South Africa (Gianokos, 1999). This includes the failure to account for environmental and social factors fully which may have a bearing on career decisionmaking and career development (Naicker, 1994). 
Thirdly, a growing body of literature appears to question the developmental view of career decision-making (Bright, Pryor, Chan \& Rijanto, 2009; Henneberger \& Sousa-Poza, 2007; Hirshi \& Vondracek, 2009). They are of the opinion that in present-day economies, individual career development could be a dynamic process instead of it being static or rational, as assumed in developmental views of career decision-making (Savickas et al., 2009).

The developmental view of career decision-making, although having concerns, still receives attention. Brown (1999) commends it as laudable in helping to understand the nature of career decision-making. In addition to this, tools and instruments used in career assessment and career guidance still hinge on the developmental view of careers (Zunker, 2002).

Finally, Bloch's theory of career decision-making investigated aspects of complexity and emergent opportunities in decisionmaking (Bloch, 2005). In this, the process of decision-making is believed to be one of tangential movements, disjointed job choices and is based on the emergence of opportunities (Young, 2009). In Bloch's theory, formal descriptions of reasoning and planning that characterise long-term careers are not realistic and are described as based on opportunities and demands that become available (Bloch, 2005). In essence, career decision- making is assumed as being fluid and not always occurring in a logical progression (Giles \& Larmour, 2000; LaPointe, 2010; Maree \& Beck, 2004).

It can also be assumed that career change as part of the career development process arises because of perceived individual needs or the lack of them (Bloch, 2005; McMahon, 2006). This makes an individual search for a change to their current situation. However, the fact that individuals have bounded rationality (Simons, 1994) affects the process of decisionmaking. This can result in bias and the individual searching for more information to help make decisions (Nadkarni \& Barr, 2008).

The current work was motivated by the need to study career change as part of the career development process separate from the quantitative paradigm. Rather, a qualitative investigation was adopted. This was done for three reasons. Firstly, traditional career theories have been criticised for their neglect of women and minority groups in their theorising (Osipow \& FitzGerald, 1996) given that these people face unique challenges (Brown, 1990). These theories have been attributed mostly to White men in Western countries and do not reflect the situation in South Africa (Stead \& Watson, 2006). This study seeks to investigate the career change experience of an often neglected yet important constituency in previously disadvantaged individuals.

Secondly, given that South Africa is undergoing rapid social, economic and political change (Stead, 2007) this brings into question the veracity of traditionally held views of career decision- making in such contexts. Arising from this, this study investigated the career change experience of previously disadvantaged groups in contexts such as South Africa. This investigation moves away from just identifying factors influencing career change and extends to an understanding of the entire experience.

Thirdly, objective data has been generated using mostly quantitative research design to understand career decisionmaking in South Africa, as already stated. These studies hinge on instruments developed in a Western context, a fairly different domain to that of South Africa. An opportunity thus exists for generating subjective data in careers research (Lamprecht, 2002) as a potential contribution to an already saturated research field. This is regarded as forming the 'new' careers literature agenda (Chudzikowski, 2012, p. 298). This places the impetus for this study on understanding career behaviour such as career change using a qualitative approach (Wise \& Milward, 2005). This study did this using a narrative and story-telling inquiry.

\section{Using narratives to understand career change}

The use of the qualitative approach for the study of new definitions for a career has been applauded (Chudzikowski, 2012) but a review of the literature reveals that it has rarely been used in investigations of career change (Wise \& Milward, 2005).

According to Cohen and Mallon (2001), a narrative inquiry entails understanding:

ways in which individuals make sense of their careers as they unfold through time and space, attending to both the holistic nature of careers as well as to specific career transitions. (pp. 48-49)

This consists of a scheme by which human beings make their experiences meaningful (Bruner, 1986; Polkinghorne, 1988) through the stories they tell (Abbot, 2002). Consistent with the narrative inquiry is the contextual action theory (Valach \& Young, 2002) that views life career action as an 'ongoing, ever-changing and holistic experience' in the individual's life (Wise \& Milward, 2005, p. 401). Stemming from this, narratives based on the stories individuals tell can tap into highlighting the complexities brought forward by micro and macro factors and their influence in career development, specifically career change.

This research study extended a growing body of work using qualitative methods to understand career change internationally (Wise \& Milward, 2005) by using narrative inquiry to understand career development in South Africa (Geldenhuys \& De Lange, 2007; Maree \& Beck, 2004; Maree, Ebersöhn \& Molepo, 2006). This represented a novel process in understanding not just career decision-making but aspects of career change apart from the dominant quantitative research method.

\section{Research design Research approach}

A qualitative approach was followed in this research by adopting an interpretive research philosophy (Creswell, 2009). This philosophy is based on individual experience and 
interpretation. The emphasis is on understanding meaning and how the individual interprets what is deemed as social reality. In this case, the research investigated the career change experience from the lens of previously disadvantaged individuals.

\section{Research strategy}

Twenty participants took part in this study and were enrolled as distance learners. The majority of participants were Xhosa speaking. Thirteen women and seven men were interviewed. The age groups of these participants ranged from 29 to 45 and are reported in Table 1 . The majority of participants were enrolled in undergraduate courses with only five pursuing post-graduate courses. Table 1 gives an outline of the participants in this study.

\section{Research method}

\section{Research setting}

The research was conducted in the Eastern Cape of South Africa at the campus of a leading distance learning provider in South Africa.

\section{Entrée and establishing researcher roles}

Ethics approval was attained through the participating and hosting institutions before commencing data collection. Interviews were arranged with participants and conducted at the convenience of the participants in a dedicated office. The researcher personally contacted each prospective participant to the study and explained the context and purpose of the study before participation. Thus, the duties of the researcher covered the recruitment and the data collection phases of this research. All research participants voluntarily took part in the study and their rights were communicated before the

\begin{tabular}{|c|c|c|c|}
\hline Code & Age & Gender & Career change \\
\hline W1 & 29 & Man & Self-employed to marketing \\
\hline W2 & 30 & Woman & Admin clerk to HR practitioner \\
\hline W3 & 36 & Woman & Secretary to HR generalist \\
\hline W4 & 29 & Woman & Admin clerk to HR practitioner \\
\hline W5 & 45 & Man & Teacher to IT consultant \\
\hline W6 & 29 & Woman & Secretary to psychologist \\
\hline W7 & 27 & Woman & Purchasing to auditing \\
\hline W8 & 27 & Man & $\begin{array}{l}\text { Motor mechanic to music performer or } \\
\text { educator }\end{array}$ \\
\hline W9 & 35 & Man & Teaching to accountant \\
\hline W10 & 27 & Woman & Sales agent to HR generalist \\
\hline W11 & 28 & Woman & Musician or producer to teaching \\
\hline W12 & 29 & Woman & Sales agent to banking (accounts) \\
\hline W13 & 29 & Man & Engineering to theology \\
\hline W14 & 36 & Woman & Self-employed to police officer \\
\hline W15 & 30 & Woman & $\begin{array}{l}\text { Civil engineering to construction } \\
\text { management }\end{array}$ \\
\hline W16 & 34 & Woman & Secretary to teaching \\
\hline W17 & 29 & Man & Store operative to law \\
\hline W18 & 40 & Man & $\begin{array}{l}\text { Marketing to psychology or community } \\
\text { pastor }\end{array}$ \\
\hline W19 & 41 & Woman & $\begin{array}{l}\text { Secretary to HR specialist (learning } \\
\text { development) }\end{array}$ \\
\hline W20 & 29 & Woman & Accounting to law \\
\hline
\end{tabular}

$H R$, human resource; IT, information technology. start of the interview. This included the right to withdraw at any point of the interview and for collected data to be deleted in their presence.

\section{Sampling}

Convenience sampling (Cohen, Manion \& Morrison, 2007, p. 114) was used for this research and allowed the researcher to identify 'available and accessible' participants to the study. The distance learning centre was a strategic hub in which to access these students as it served as a convenient meeting place for students, staff and for finding learning materials.

The study paid attention to an inclusion and exclusion criteria. Participants to the study had to be registered and have valid student status with the distance-learning university. In addition to this, participants had to fit in with the criteria recognised by law of being previously disadvantaged either by race or by gender (Cottrell, 2005). Participants were excluded if they did not meet this criterion.

\section{Data collection methods}

Unstructured interviews were used as the main method of data collection as a mechanism through which the meaning of behaviours and events in people's lives were conveyed in the natural flow of a conversation (Patton, 2002). Individual interviews offered opportunity to gather data that was unaffected by members of the group. These conversations allowed for the triggering of memories, reflection on experiences, elaboration of ideas and clarification of responses (Rubin \& Rubin, 2005).

The interview methodology employed in this study was informed by the model of constructing narratives for critical social inquiry with a view to generating detailed accounts rather than brief answers or general statements (Riessman, 2008). Emphasis was also placed on the importance of meaning and subjectivity through the interaction of participants rather than a discrete exchange of questions and answers (Rubin \& Rubin, 2005). The central tenet here was that narrated experiences are socially constructed and that there can be many different constructions of events, each of which is true and unique (Rubin \& Rubin, 2005). Each of the interviews lasted between 45 and $90 \mathrm{~min}$.

\section{Recording of data}

The interviews were recorded and transcribed verbatim. Interview transcripts then served the purpose of further data analysis

\section{Data analyses}

The analysis of the interview data was done using QSR Nvivo 8 - a data management software. The data analysis technique used was based on previous work done using narratives in understanding human experience (McCormack, 2000; Rhodes, 2000). This procedure was based upon three levels of meaning. Firstly, the content of each interview was written as a brief vignette and then into a longer narrative about 
each participant. The purpose here was to help develop a good understanding of the career development experience (including the aspects of career change). This was done by re-reading each interview and listening to audio recordings. McCormack (2000, p. 221) advised that each narrative be scanned for 'markers' of stories, namely, orientation, abstract, what happened, evaluation and coda. The basic goal of this stage was to enter into the emotion and details as defined by the storyteller. This type of interrogation was viewed as allowing for a key question to be answered about each interview, '... what kind of story is this?' (Thornhill, Clare \& May, 2004, p. 188). Based upon this, a basic understanding of each participant's story was compiled.

Secondly, a level of meaning-making was used. This involved identifying the narrative themes which were conveyed by the participant and their career change experience. Preliminary themes from each interview were identified whilst setting for cross-case comparison. This also entailed a process of coding which was based on classifying responses into meaningful categories (Nachmias \& Nachmias, 1996). By identifying common themes and regularities the aim was to discover how widespread the career development experiences were amongst all of the participants' stories. To achieve this means of analysis, the use of narrative processes as tools with which to enhance and give meaning to a story were considered (McCormack, 2000).

A final means of data analysis entailed analysing the content of the gathered narrative accounts and themes (McCormack, 2000). This was done by identifying themes and using quotes based on consistencies across participant stories (Rhodes, 2000).

\section{Strategies employed to ensure quality data}

Issues of reliability and validity in this study were addressed using various prescribed guidelines (Creswell, 2009). The internal reliability of this study was enhanced in the following ways. Firstly, rich and thick descriptions of the data were formulated in order to allow readers to make decisions regarding the scientific merit of the findings. This is important, especially when there is need to understand career behaviour from a multi-cultural context with the ultimate purpose of sharing the results on an international scale. Secondly, data was gathered over a period of time in order to avoid participant and interviewer fatigue. Finally, in order to ensure that all the data was accurately recorded, interviews were audiotaped and extensive notes were taken during the fieldwork (Creswell, 2009).

\section{Reporting}

The main findings from the analysis will be presented as (1) sources of career change, (2) effects of career change and (3) the role of distance learning enrolment on individual career change. Participant stories and narratives are used to illustrate this. However, because of length restrictions the most salient stories and quotes are given focus.

\section{Findings Source of career change}

Career change was attributed as a source of two identified themes in the participants' stories and narratives. These included reasons attributed to (1) personal growth and ambition and (2) structural changes in current work or job.

Personal growth and ambition served as the most salient theme for necessitating individual career change. Within this theme, variation existed amongst participant stories and narratives. Some participants cited the need to develop further and the only way to do this was through a career change.

W12 was working as a sales agent for a reputable South African marketing company, a job which was 'tedious' and 'monotonous'. Interestingly, W12 makes reference to the influence of apartheid in telling her career change story:

'The accounting profession in the past, that is, during the apartheid era was restricted to only a select few. So coming from the marginalised group on the basis of colour and gender I wanted to actually break these barriers. There are still a few Black people who are CA's, some are just accountants. For me, I wanted to go all the way. This was enough motivation to make the move to banking and hopefully become an accountant within my bank.' (W12, woman, 29)

In the same way as W12, other participants brought forward the issue of apartheid in explaining their career change story (W5 and W19). The story and narrative of W5 receives attention as an illustration. W5 made specific inference to pre-apartheid and post-apartheid South Africa. During preapartheid South Africa:

'I started off as a teacher in Motherwell. I grew up in the apartheid days and in those days as a Black person you did not have much for you. It's either you became a teacher, nurse or a general hand. My father worked for a school in the township and was an educator and he instilled the value of education. I actually think I became a teacher just after him.' (W5, man, 45)

W5 did not offer any valence between the influence of apartheid or his father regarding his career decisionmaking. However, the impact of both appears inevitable, given his narration. This was made apparent in a further quote detailing how W5 'made the shift from teaching to Information Technology':

'... you know as Black people we were stopped from getting into
some of these professions; this is good for us in the new South
Africa. We just need to continue working hard and to show people
not happy with this, that we can also do well.' (W5, man, 45)

The above quote was interesting and laden with a sense of racial identity through the use of the possessive pronoun ' $w e^{\prime}$. Here W5 appeared to identify himself with the cause of Black people who were denied opportunities during apartheid. To W5, the transition from a pre-apartheid to post-apartheid dispensation offered an opportunity for career development, specifically a career change. 
In some stories, individual's lack of interest in their current career facilitated career change. This was significant amongst the majority of participants (W1, W2, W3, W6, W7, W10, W13, W9 and W12). An illustration of this is the story of W9 who had worked for over 5 years as a secretary. The motivation to be a secretary had been influenced by the portrayal of this career as being one of 'glamour and fame'. However, after working for five years W9 narrated her experience:

'... I thought being a secretary was about glamour and fame. However, I soon was caught in routine work and realised that this was not my thing. I made the change to psychology.' (W9, man, 35)

Career change necessitated by a quest to develop oneself further illustrates how the notion of a career is unpredictable, messy and intricate. Individual career decisions do not appear to be set in stone or fixed but open to a process of negotiation.

Structural changes in an individual's current job or work were another identified source of career change amongst participant stories. This covered any interruption to an individual's job or work caused by redundancy, retrenchment or unemployment. Subsequently, from these experiences individuals made the decision to change careers. Some examples from the respondents are used to illustrate this below.

W9 experienced retrenchment whilst working for a large motor manufacturing company in the Eastern Cape:

'I was working as an operator building engines at different stations. I got retrenched and this was just beyond me as the company was cutting down on staff. It was a tough job but I was so happy to be retrenched as that gave me opportunity to try other things.' (W9, man, 35)

W9 appeared happy with being retrenched so that he could 'try other things'. W9 turned to studying as a way to improve his chances of securing employment and enrolled to study after a suggestion from a friend that he pursue a degree with double majors in 'commerce and education' (B Com Ed). This was strategic for the purpose of securing specialisation in the 'corporate world or education sector'.

W9 turned to a career working as a teacher in Port Elizabeth. He did not enjoy the teaching job:

\footnotetext{
'I was teaching life science, business economics and computer science. I discovered within education there was no personal growth. You remain a post-level teacher before you can go up the ladder. The reason is you have to wait for someone to die to get a position. Take for example; being a principal you have to wait for the current principal to retire or die ... the kids were disrespectful ... it affects and discouraged me and I knew this was not my thing. I decided to leave. Also as a temporary teacher with no promise of employment and so I took the risk.' (W9, man, 35)
}

W9 recounted many stories, all of which seemed to be rooted in the theme of being unemployed. These stories showed patterns of broken employment and working part-time. This movement appeared to show two things. Firstly, W9's work history demonstrated his desire to construct his career. Secondly, and related to the first, the changes in jobs and careers in W9's story presented opportunities and constrains in this career construction. This appears to paint a picture of the complexity and unpredictability of career change.

Participant W16 also went through a period of being unemployed for 'over ten years' with temporal work opportunities described as 'piecejobs' that helped her survive. This participant bemoaned of how she acquired these 'piece jobs' using her Matric certificate not her degree. Participant W16 managed to get a job as a secretary. It is during the period of being unemployed and going through various piece jobs that the decision was made to change from being a secretary to a teacher. This was motivated by the perception of 'stability of income' and 'abundant opportunities' in the teaching profession.

Participant W16's account is similar to that of W12. She also used her circumstance of being unemployed after working as a 'sales agent' to charter a way forward into a new career in auditing in a bank. A decision she describes as a 'gamble' that eventually 'paid off', albeit the 'uncertainty'.

Being unemployed appeared to be a paradox as found through participant stories and narratives including the ones not used for empirical illustration. At first, the state of being unemployed emerged as a constraint to an individual's current career trajectory. However, it was also an opportunity to try new things thus facilitating a career change. This opportunity was not optional but mandatory in the quest for the individual to survive and also earn a living.

\section{Effects of career change}

The effect of the career change experience based on participants' stories and narratives was also ascertained. This experience had an influence on individual well-being. This highlighted how emotive the period of career change can be. It is a process filled with uncertainty and takes a toll on the individual. An example to illustrate this is the journey taken by W13 from being an engineer to a pastor, 'It was a difficult decision that took me a year and half to decide. A decision that was physically straining' (W13, man, 29).

Other participants corroborated the same sentiments as W13:

- 'I felt I had made the wrong decision based upon what I had studied. It did not feel good' (W2, woman, 30).

- 'Being retrenched is not a nice feeling. On the one hand is this unknown about what is going to happen ... then the thought of how you will provide for the family' (W18, man, 40).

- 'I was panicking because I had graduated and I was supposed to be the one who was helping and supporting my parents instead I was the one getting the support. I lost my self-esteem when I could not get a job' (W16, woman, 34). 


\section{Role of distance learning enrolment on individual career change}

Through participants' stories and narratives the role of distance learning enrolment on the career change experience was ascertained. Distance learning allowed an individual to rise above the challenge of disadvantage and also to negotiate around this by attaining an educational qualification. This helped the individual move to a desired career. Although distance learning occupied a pragmatic consideration because it was cheap, education was viewed as a way of facilitating career change. The attainment of an education through distance learning thus occupied importance in the stories of the previously disadvantaged distance learners.

W16, after years of working as a secretary and making the change to teaching, stated, 'I do have hope that this postgraduate certificate will make me more marketable' (W16, woman, 34). W14 had a similar experience. She worked as a police officer after being self-employed and described the rationale for distance learning as dual. Firstly, it 'allows for flexibility of being a mom and a professional' (W14, woman, 36) and secondly 'I think the diploma will help me climb the ranks, as it will be easy to get a promotion upon completion' (W14, woman, 36).

Finally, all of the participants affirmed the role distance learning played during their career change experience. A common theme that ran across all of the participants' stories and narratives in the career change experience was that distance learning was a cheap mode of study, thus facilitating career change:

- 'I did not have money to study full-time. So I started working part-time to save money to study via distance learning. The fees are lower than other universities' (W9, man, 35).

- 'Distance learning is cheaper as I can't afford full-time study' (W19, woman, 41).

\section{Ethical considerations}

Participants to the research were informed of their rights including the voluntary nature of the research and consent was mandatory before commencing the research. Pseudonyms were used to disguise participant names as a measure to protect them.

\section{Discussion}

The main purpose of this study was to investigate the career change experience amongst previously disadvantaged individuals in South Africa. From the participants' stories a common theme appeared which was the desire to enact career choice especially when faced with situations necessitating career change. This study attests to the emerging trend of periodic employment and change in jobs or careers in present day economies as influencing an understanding of careers (Hall, 2004). Thus, the process of career decisionmaking was found to be non-linear, non-stable and without a logical progression. This study found career change as being based on complexity and emergent opportunities affecting individuals (Bloch, 2005).

From the analysis of the data, the career change experience was rooted in a societal and cultural context. This was often cited when explaining this experience. This study thus confirms previous findings that demonstrated the influence of such a context on individual career decision-making in South Africa (Geldenhuys \& De Lange, 2007; Jordaan et al., 2009; Myburgh, 2005; Watson et al., 2001). Uniquely this is done by investigating the career change process.

This study also demonstrated how the process of enacting career change decisions occurs as a socially constructed phenomenon. This revelation may have come about as a result of the narrative analysis which enabled a more indepth look into this complex phenomenon. Thus, career change, apart from being 'personal' and 'highly complex' (Wise \& Milward, 2005, p. 401) was found to be a process of individual performance and co-construction (LaPointe, 2010). Factors identified in this research such as the quest for personal growth and ambition, and structural changes related to the work or job situation informed this process.

The role of education, particularly distance learning, was found important in helping individuals facilitate the process of their career change. This supports previous work in South Africa that demonstrated the role of education on individual career development (Geldenhuys \& De Lange, 2007; Jordaan et al., 2009; Myburgh, 2005; Watson et al., 2001). Uniquely, the benefits of distance learning identified in the literature were also found to be important to the career change experience (Glennie \& Bialobrzeska, 2006; Lemmer, 2009). The thinking here is that distance learning occupies a pragmatic function which cannot be divorced from individual needs or the circumstances surrounding disadvantage. This was an imperative which was manifest in how participants engaged in the dual responsibility of work and study, and the flexibility which was required to maintain this balance. In essence, this assisted the career change experience by acquiring a qualification to support this. Distance learning thus created a space not just for acquiring an education but aiming for mobility from one career to another. It was a bridge for moving out of a career and the quest for a better life considering the individual situation and background in South Africa.

Theoretically, the findings of this work do not negate assertions held in traditional career theories. For instance, individual traits and interests as suggested in the trait and factor theory (Holland, 1992, 1997) were found to inform decisions on career change. This was often cited when individuals justified career change based on personal interests and consideration. 
In addition to this, enactment of career decisions entailed constant revision. In turn, this negated the idea of a career as being a linear and predictable process held in the developmental view of careers. Career development in this study was a continuous life project with no fixed state of arrival, but instead characterised by constant revision regardless of individual experiences of work and study. Career change bore evidence to this and supported empirical work showing the constant revision of a career especially in rapidly unstable contexts (Henneberger \& Sousa-Poza, 2007; Hirshi \& Vondracek, 2009).

Practical implications can be suggested from this research. Given the perceived benefit of distance learning, especially amongst previously disadvantaged individuals, building more of such universities may make sense. Given that cost consideration is cited as a barrier by previously disadvantaged individuals entering full-time study and access to education (Msila, 2006), this study magnifies the important role of distance learning. This suggestion has implications not just on improving access to education but also for the social justice agenda in South Africa.

Practical interventions targeted at those distance learners undergoing career change can be suggested. For example, training interventions dealing with how to balance the demands of life roles including study and employment are warranted. This is needed given that these issues were salient in participants' stories and narratives.

The findings from the research are likely to be of value to human resource practioners who will work with individuals undergoing or contemplating career change. Understanding the factors motivating this provides a useful starting point for retention strategies and improving individual jobs and careers.

\section{Limitations of the study}

The study has notable limitations. Concern was raised over the small number of respondents interviewed. A small number of respondents were used for the purpose of making a theoretical argument and to illustrate the merit of qualitative methods in providing a deeper understanding of career development and career change. This was useful in generating theory around such career behaviours.

Notwithstanding such limitations, this study also placed importance on understanding the role of context, historical consideration and disadvantage when it came to the career change experience. Future research could extend from this by means of continued investigation of such phenomenon in South African organisations. Finally, future research could also investigate career change behaviour outside the distance learning context as a basis for comparison.

\section{Conclusion}

This study offered an interesting exploration of how complex variables influence career change in South Africa. In doing so, the study has focused on the need to understand such behaviour using methods and research design that have not traditionally received attention. Sources of individual career change were identified including their effect on individual well-being. By utilising this knowledge, solutions may be suggested. Uniquely, focus was given to distance learning as an opportunity and prerequisite for individual career development, especially for the previously disadvantaged in South Africa.

\section{Acknowledgements}

An earlier version of this paper was presented at the Gender, Work and Organisation: 7th Biennial International Interdisciplinary Conference, hosted by Keele University in June 2012.

\section{Competing interests}

The author declares that is no financial or personal relationship(s) which may have inappropriately influenced him in writing this paper.

\section{References}

Abbot, H. (2002). The Cambridge introduction to narrative. Cambridge, UK: Cambridge University Press.

Arnold, J. (1997). Managing careers into the twenty-first century. London: Pau Chapman.

Arnold, J., \& Cohen, L. (2008). The psychology of careers in industrial-organizational settings: A critical but appreciative analysis. In G.P. Hodgkinson \& J.K. Ford (Eds.), International Review of Industrial/Organizational Psychology, 23, 1-44. Chichester: Wiley.

Baruch, Y. (2004). Managing careers: Theory and practice. Harlow: FT-Prentice Hall/ Pearson.

Bem, D.J. (1967). Self-perception: An alternative interpretation of cognitive dissonance phenomena. Psychological Review, 74, 183-200. http://dx.doi.org/10.1037/ h0024835, PMid:5342882

Bloch, D.P. (2005). Complexity chaos and nonlinear dynamics: A new perspective on career development theory. Career Development Quarterly, 53, 194-207. http:// dx.doi.org/10.1002/j.2161-0045.2005.tb00990.x

Bono, J.E., \& Vey, M.A. (2007). Personality and emotional performance: Extraversion, neuroticism, and self-monitoring. Journal of Occupational Health Psychology, 12, 177-192. http://dx.doi.org/10.1037/1076-8998.12.2.177, PMid:17469999

Booysen, A.E. (2000). Towards a more feminine business leadership for the 21st century: A literature review and a study of the potential implications for South Africa. South African Journal of Labour Relations, 1(23), 31-54.

Bosch, A., De Bruin, G.P., Kgaladi, B., \& De Bruin, K. (2012). Life role salience among black African dual-career couples in the South African context. The International Journal of Human Resource Management, 23(14), 2835-2853. http://dx.doi.org/ 10.1080/09585192.2012.671506

Bright, J.E.H., Pryor, R.G.L., Chan, E., \& Rijanto, J. (2009). The dimensions of chance career episodes. Journal of Vocational Behavior, 75(1), 14-25. http://dx.doi. org/10.1016/j.jvb.2009.02.007

Brown, A., Bimrose, J., Barnes, S.A., \& Hughes, D. (2012). The role of career adaptabilities for mid-career changers. Journal of Vocational Behaviour, 80(3), 754761. http://dx.doi.org/10.1016/j.jvb.2012.01.003

Brown, D. (1990). Summary, comparison and critique of the major theories. In D. Brown, L. Brooks \& Associates (Eds.), Career Choice and Development. San Francisco: Jossey - Bass.

Bruner, J.S. (1986). Actual minds, possible worlds. Cambridge. MA: Harvard University Press.

Burgess, J.R.D., \& Russell, J.E.A. (2003). The effectiveness of distance learning initiatives in organizations. Journal of Vocational Behavior, 63(2), 289-303. http:// dx.doi.org/10.1016/S0001-8791(03)00045-9 
Chen, Y., \& Fang, W. (2008). The moderating effect of impression management on the organizational politics-performance relationship. Journal of Business Ethics, 79, 263-277. http://dx.doi.org/10.1007/s10551-007-9379-3

Chudzikowski, K. (2012). Career transitions and career success in the 'new' career era. Journal of Vocational Behaviour, 81(2), 298-306. http://dx.doi.org/10.1016/j. jvb.2011.10.005

Cohen L., \& Mallon M. (2001). My brilliant career? Using stories as a methodological tool in careers research. International Studies of Management and Organization, $31(3), 48-68$.

Cohen L., Manion, L., \& Morrison, K. (2007). Research methods in education. (6th edn.). London: Routledge-Falmer.

Cohen, A. (2003). Multiple commitments in the workplace: An integrative approach Mahwah, NJ: Lawrence Erlbaum Associates.

Cottrell, R. (2005). South Africa: A state of apartheid. New York: Chelsea House.

Creed, P.A., Patton, W., \& Watson, M.B. (2002). Cross-cultural equivalence of the career decision-making self-efficacy scale-short form: An Australian and South African comparison. Journal of Career Assessment, 10, 327-342. http://dx.doi. org/10.1177/10672702010003004

Creswell, J.W. (2009). Research design: Qualitative, quantitative and mixed methods. (3rd edn.). Los Angeles: Sage.

Czakan, P. (2006). Retention of workers in telecommunications. Unpublished MBA thesis, University of Cape Town, Cape Town, South Africa.

Du Toit, R., \& De Bruin, G.P. (2002). The structural validity of Holland's R-I-A-S-E-C model of vocational personality types for young black South African men and women. Journal of Career Assessment, 10, 62-77.

Geldenhuys, J., \& De Lange, N. (2007). Career identities of first-year female coloured students. South African Journal of Education, 27, 117-137.

Gianokos, I. (1999). Career counselling with battered women. Journal of Mental Health Counseling, 21, 1-14.

Gibson, R.L., \& Mitchell, M.H. (1999). Introduction to counseling and guidance. (5th edn.). Upper Saddle Rive, NJ: Prentice Hall.

Giles, M., \& Larmour, S. (2000). The theory of planned behaviour: A conceptual framework to view the career development of women. Journal of Applied Psychology, 30(10), 2137-2157. http://dx.doi.org/10.1111/j.1559-1816.2000. tb02429.x

Glennie, J., \& Bialobrzeska, M. (2006). Overview of distance education in South Africa. Johannesburg: SAIDE.

Hall, D.T. (2002). Careers in and out of organizations. Thousand Oaks: Sage.

Hall, D.T. (2004). The protean career: A quarter-century journey. Journal of Vocational Behavior, 65, 1-13. http://dx.doi.org/10.1016/j.jvb.2003.10.006

Henneberger, F., \& Sousa-Poza, A. (2007). Arbeitsplatzstabilität und arbeitsplatzwechse in der Schweiz [Employment stability and job mobility in Switzerland]. Bern: Haupt.

Herr, E.L., \& Cramer, S.H. (1992). Career guidance and counselling through the life span: Systematic approaches. New York: Harper Collins.

Herr, E.L., Cramer, S.H., \& Niles, S.G. (2004). Career guidance and counselling through the lifespan: Systemic approaches. (6th edn.). Boston: Allyn \& Bacon.

Hess, N., Jepsen, D.M., \& Dries, N. (2012). Career and employer change in boundaryless career. Journal of Vocational Behaviour, 81, 280-288. http://dx.doi.org/10.1016/j jvb.2011.10.009

Hirshi, A., \& Vondracek, F. (2009). Adaptation of career goals in early adolescence to self and opportunities. Journal of Vocational Behaviour, 75(2), 120-128. http:// dx.doi.org/10.1016/j.jvb.2009.05.005

Holland, J.H. (1997). Making vocational choices: A theory of vocational personalities and work environments. (3rd edn.). Englewood Cliffs, NJ: Prentice-Hall.

Holland, J.L. (1992). Making Vocational Choices: A theory of vocational personalities and work environments. (2nd edn.). Odessa, FL: Psychological Assessment Resources.

Ibarra, H. (2003). Working identity: Unconventional strategies for re-inventing your career. Illinois: Harvard Business Press.

Inkson, K. (2007). Understanding careers: The metaphors of working lives. London: Sage Publications

Jordaan, Y., Smithard, C., \& Burger, E. (2009). Comparing levels of career indecision among selected honours degree students at the University of Pretoria. Meditari, $17(2), 1-15$

Krumboltz, J.D. (1979). A social learning theory of career decision-making. In A.M. Mitchell, G.B. Jones \& J.D. Krumboltz (Eds.), Social Learning and Career Decision Making. Cranston, RI: Carroll Press. PMid:20738188

Lamprecht, J.C. (2002). Career assessment skills. In K. Maree \& L. Ebersohn, Life Skills in Career Counselling. Sandown, Heinemann.

LaPointe, K. (2010). Narrating career, positioning identity: Career identity as a narrative practice. Journal of Vocational Behaviour, 77, 1-9. http://dx.doi.org/10.1016/j. jvb.2010.04.003

Lemmer, E.M. (2009). Empowerment of women students through educational achievement: A narrative inquiry. African Education Review, 6(1), 80-95. http:// dx.doi.org/10.1080/18146620902857319

Lent, R.W., Brown, S.D. \& Hackett, G. (2002). Social cognitive career theory. In D. Brown $\&$ Associate (Eds.), Career choice and development. (4th edn.). San Francisco, CA Jossey-Bass.
Maree, J.G., \& Beck, G. (2004). Using various approaches in career counselling for traditionally disadvantaged learners: Some limitations of a new frontier. South African Journal of Education, 24, 80-87.

Maree, K. (2002). Theoretical approaches: An overview. In K. Maree \& L. Ebersöhn (Eds). Life Skills and Career Counselling (n.p.). Sandown: Heinemann Publishers.

Maree, K., Ebersöhn, L., \& Molepo, M. (2006). Administering narrative career counselling in a diverse setting: Trimming the sails to the wind. South African Journal of Education, 26, 49-60.

Marshall, V., \& Bonner, D. (2003). Career anchors and the effects of downsizing: Implications for generations and cultures at work: A preliminary investigation. Journal of European Industrial Training, 27(6), 281-291. http://dx.doi. org/10.1108/03090590310479910

McCormack, C. (2000). From interview transcript to interpretative story: Part 1. Viewing the transcript through multiple lenses. Field Methods, 12(4), 282-297. http://dx.doi.org/10.1177/1525822X0001200402

McFarland, L.A., Yun, G., Harold, C.M., Viera, L., Jnr., \& Moore, L.G. (2005). An examination of impression management use and effectiveness across assessment center exercises: The role of competency demands. Personnel Psychology, 58, center exercises: The role of competency demands. Personnel $P$
949-980. http://dx.doi.org/10.1111/j.1744-6570.2005.00374.x

McMahon, M. (2006). Career counselling: Applying the systems theory framework of career development. Journal of Employment Counseling, 32, 29-38.

Mitchell, L.K., \& Krumboltz, J.D. (1996). Krumboltz's learning theory of career choice and counselling. In D. Brown, L. Brooks \& Associates (Eds.), Career Choice and Development. (3rd edn.). San Francisco, California: Jossey-Bass.

Msila, V. (2006). School choice - as if learners matter: Black African learners' views on choosing schools in South Africa. Mevlana International Journal of Education, $57(1), 1-14$

Myburgh, J.E. (2005). An empirical analysis of career choice factors that influence first-year accounting students at the University of Pretoria: A cross-racial study. Meditari Accountancy Research, 13, 35-48. http://dx.doi. org/10.1108/10222529200500011

Nachmias, F.C., \& Nachmias, D. (1996). Research Methods in the Social Sciences. (5th edn.). New York: Worth Publishers.

Nadkarni, S., \& Barr, P.S. (2008). Environmental context, managerial cognition and strategic action: An integrated view. Strategic Management Journal, 29, 13951427. http://dx.doi.org/10.1002/smj.717

Naicker, A. (1994). The psycho-social context of career counselling in South African schools. South African Journal of Psychology, 24(1), 27-34.

Oleski, D., \& Subich, L.M. (1996). Congruence and career change in employed adults. Journal of Vocational Behaviour, 49, 221-229. http://dx.doi.org/10.1006/ jvbe.1996.0041

Osipow, S.H., \& FitzGerald, L.F. (1996). Theories of career development. Boston, MA: Allyn \& Bacon

Patton, M.Q. (2002). Qualitative Research and Evaluation Methods. Thousand Oaks, CA: Sage.

Patton, W., Creed, P.A., \& Watson, M. (2003). Perceived work related and non-work related barriers in the career development of Australian and South African adolescents. Australian Journal of Psychology, 55, 74-82.

Polkinghorne, D.E (1988). Narrative knowing and the human sciences. Albany, NY: State of New York University Press.

Rhodes, H. (2000). Mid-life career change to home-based self-employment in a group of women. Unpublished master's dissertation, Simon Fraser University, British Columbia, Canada.

Riessman, C.K. (2008). Narrative Methods for the Human Sciences, Los Angeles, CA: Sage.

Rubin, H.J., \& Rubin, I. (2005). Qualitative interviewing: The art of hearing data. Thousand Oaks: CA: Sage.

Savickas, M., Nota, L., Rossier, J., Dauwalder, J.P., Duarte, M.E., Guichard, J. et al (2009). Life designing: A paradigm for career construction in the 21 st century. (2009). Life designing: A paradigm for career construction in the 21st century.
Journal of Vocational Behaviour, 75(3), 239-250. http://dx.doi.org/10.1016/j. journal of Voca

Schultheiss, D., \& Stead, G.B. (2004). Childhood career development scale: Scale construction and psychometric properties. Journal of Career Assessment, 12, construction and psychometric properties. Journal of Car
113-134. http://dx.doi.org/10.1177/1069072703257751

Simons, R. (1994). How new top managers use control systems as levers of strategic renewal. Strategic Management Journal, 15, 169-189. http://dx.doi.org/10.1002/ smj.4250150301

South African Department of Education. (1997). Curriculum 2005: Discussion document. Pretoria: Government Printers.

South African Department of Education. (2010). Education statistics in South Africa 2009. Department of Education, Pretoria.

Stead, G.B. (2007). Cultural psychology as a transformative agent for vocational psychology. International Journal for Educational and Vocational Guidance, 7 , 181-190. http://dx.doi.org/10.1007/s10775-007-9125-5

Stead, G.B., \& Chetty, J. (2002). Construct validity of occupational awareness inventory among South African children. Paper presented at the Annual Meeting of the American Psychological Association, Chicago.

Stead, G.B., \& Watson, M.B. (2006). Career psychology in the South African context. Pretoria: Van Schaik Publishers. 
Super, D. (1990). A life-span, life-space approach to career development. In D. Brown (Ed.), Career choice and development, (n.p.). San Francisco: Jossey-Bass Publishers.

Super, D., Tiedman, D.V., \& Borrow, H. (1961). Vocational development: A symposium, personal and guidance journal. Personnel and Guidance Journal, 4O(1), 11-25. hersonal and guidance journal. Personnel and Guidance

Super, D.E. (1984). Career and life development. In D. Brown \& L. Brooks (Eds.), Career choice and development, (n.p.). San Francisco, Jossey-Bass.

Suutari, V., \& Taka, M. (2004). Career anchors of managers with Global careers Journal of Management Development, 23(9), 833-847. http://dx.doi. org/10.1108/02621710410558440

Thornhill, H., Clare, L., \& May, R. (2004). Escape, enlightenment and endurance: Narratives of recovery from psychosis. Anthropology and Medicine, 11, 181-199. http://dx.doi.org/10.1080/13648470410001678677
Toni, M.N., \& Olivier, M.A.J. (2004). Academic identities of black female first-year students. South African Journal of Education, 24, 194-199.

Valach, L., \& Young, R.A. (2002). Contextual action theory in career counselling: Some misunderstood issues. Canadian Journal of Counselling, 36(2), 97-112.

Watson, M.B., Brand, H.J., Stead, G.B., \& Ellis, R.R. (2001). Confirmatory factor analysis of the career decision-making self-efficacy scale among South African university students. Journal of Industrial Psychology, 27(1), 43-46.

Wise, A.J., \& Millward, L.J. (2005). The experiences of voluntary career change in 30 somethings and implications for guidance. Career Development International, 10(5), 400-417. http://dx.doi.org/10.1108/13620430510615328

Young, A.M. (2009). Frustration-instigated career decisions: A theoretical exploration of the role of frustration in career decisions. Human Resource Development Review, 8, 281-299. http://dx.doi.org/10.1177/1534484309337209

Zunker, V.G. (2002). Career counselling: Applied concepts of life planning. (6th edn.). Pacific Grove, CA: Brooks/Cole. 